\title{
An Economic Analysis of the Handicraft Industry in District Chitral Khyber Pakhtunkhwa
}

\author{
Mian Nasir Uddin \\ Department of Economics, Abdul Wali Khan University, Mardan \\ Khyber Pakhtunkhwa, Pakistan \\ miannasiruddin@yahoo.com \\ Muhammad Tariq \\ Department of Economics, Abdul Wali Khan University, Mardan \\ tariq_noor@awkum.edu.pk \\ Muhammad Arif Orakzai \\ Conservator Wildlife, Khyber Pakhtunkhwa \\ Wildlife Department, KP-Pakistan
}

\begin{abstract}
This study carries out an economic analysis of the handicraft industry located in the surrounding of Gol National Park, District Chitral. For this purpose, primary data has been collected through a detailed questionnaire and interview schedule from 60 respondents consisting of 40 local producers, 10 retailers and 10 customers during October, 2019. For the analysis of the data, descriptive statistics, correlation and ordinary least square techniques are used. The findings show that the weekly cost, revenue and profit of the 27 selected embroidery producers are Rs.251300, Rs.432990 and Rs.181690 respectively. Similarly, the total weekly cost, revenue and profit of 13 selected woodenware producers are Rs. 496200, Rs. 647000 Rs. 150800 respectively. Similarly, a single retailer (on average) per month revenue from handicraft products is around Rs. 51600 and his/her products per day demand is approximately eight (8) items. The findings also reveal that total household income and spending on education are positively related with the profit and revenue. And cost on material and average sale are positively related with per unit cost.

These findings suggest that effective policies are required for the promotion of handicraft industry which will reduce poverty and improve the socio-economic status of the handicraft producers in District Chitral.
\end{abstract}

Keywords: Handicrafts, Chitral Gol national park, embroidery, Woodenware.

\section{Introduction}

Chitral is one of those regions, which have a rich culture, situated in the Northern part of Pakistan. The total population of Chitral is estimated 447,362 with a total number of households 61,619 in 2017(Pakistan Bureau of Statistics, 2018). Chitral shares its border with Gilgit Baltistan and Kunar (Afghanistan). More than 95\% of inhabitants speak "Khowar" language. There are two national parks in the district namely Broghil Valley National Park and Chitral Gol national park popularly known for its flora and fauna, fascinating landscapes, lush green hills, water springs and beautiful river. These parks are surrounded by cedar trees and have a good number of species called Markhor. There are also a small number of other species like Siberian Ibex, Urial, And Asian Black Bear but still, Chitral is famous for hosting this unique wild goat that is known as Markhor amongst the national and international 
tourists. The total estimated area of Chitral Gol national park is $77.5 \mathrm{~km}^{2}$, located on $35^{\circ} 50^{\text {' }}$ N Latitude and $71^{\circ} 47^{\prime}$ E Longitude (Khan et al; 2011). The height of this park is

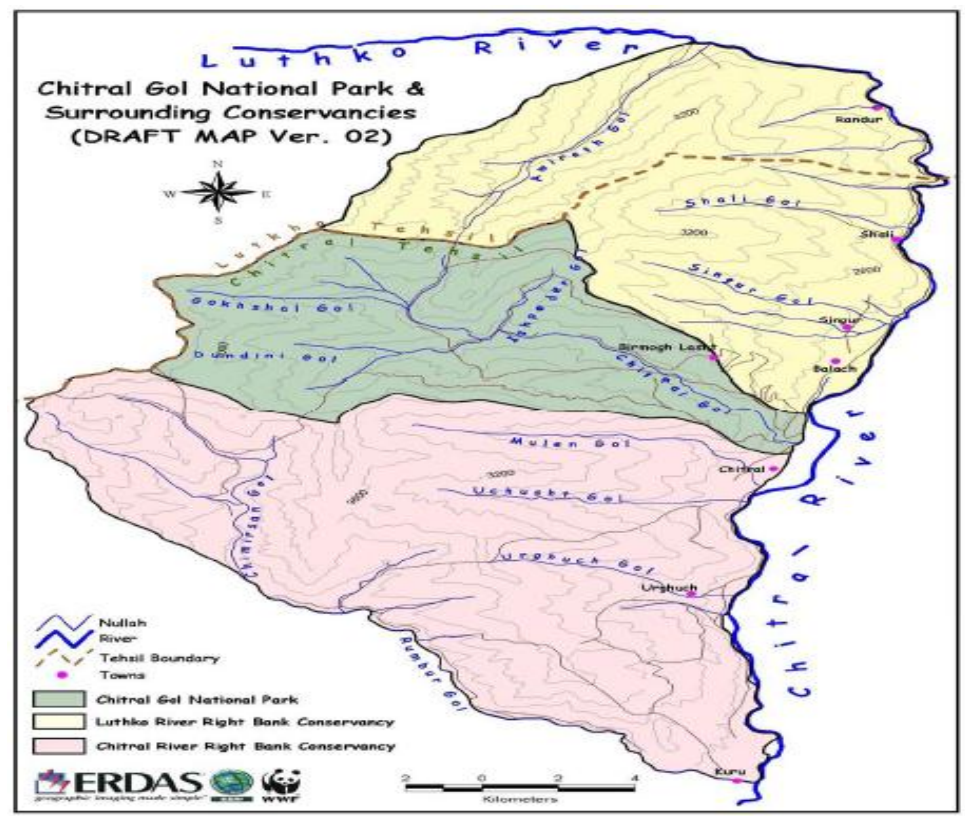

Source: Khan, et al., 2011

Figure 1: Chitral Gol National Park Map

between 1450 and 5000 meters above the sea level and located besides the Chitral River (i.e. see figure 1) at one hour drive from Chitral town. The Rumboor valley which is one of the Kalash valleys is situated in the west of the park which is connected with the park through the Chimerson track. This park shares its south boundaries with the Chitral River's right bank conservancy and northeast boundaries with Lotkoh River's right bank conservancy. Garam Chashma valley is located in the north of the park, Monoor and Beghust tracks connect this valley with the park. Chitral town is located in the east of Chitral Gol national park, a link road named Kacha connects Chitral town with the park in the East.

Chitral Gol national park has a vast and unique opportunity of handicraft businesses in its surrounding that needs to be promoted locally as well as internationally. Handicrafts are the main source of income for the local people. Chitral is rich in all kinds of handicrafts including sweaters prepared of wool with hands are very well-known. Moreover, decoration pieces, stitched clothes in different designs and other daily-use items are also popular. Likewise, Gems stones and other decoration pieces made from valuable stones are very famous. Quab Bazuri and Girvan are one of the famous embroidery design used in corner of shirts and sleeves on dresses of women. "Khoi" are special embroidered caps, some of these caps are fully embroidered called "Zurpkhoi", and some are embroidered on the corner, called "Phurisuyirokhoi". Fully embroidered are very expensive. "Chainak push" used to cover tea pot to keep it hot in the cold season, these covers are embroidered with unique patterns. "Waistcoats" is one of the important parts of weddings. Waistcoat are special embroidered jackets, it considered a very rare gift from father to her daughter on a wedding. Besides these woodenware handicrafts of Chitral are also very famous.

area.

It has been observed that there is no established channel of distribution and proper marketing for this creative and valuable work. Therefore bringing these handicrafts to other 
areas in Pakistan is extremely difficult. This sector remains a decentralized and unorganized sector of Pakistan's economy however it can be the most significant source of foreign exchange earnings. It is observed that this industry only produces for inner people's desire and fulfillment. Handicrafts of Chitral are categorized as handmade embroidery and woodenware crafts.

The handicraft industry has largely been neglected due to unawareness of households and the government. Being a main source of bread the promotion of handicrafts will have a positive impact on the lives of local inhabitants. It will attract more tourists for buying handmade embroideries and will generate income for the local producers and households. The revival of the handicraft industry in Chitral will certainly bring back handicraft experts migrated to the other part of the country for jobs. International marketing of the Chitral handicrafts will give a good name to this product and will increase the number of tourists in the area.

After reading the literature it has been noted that there is no work done on the handicraft industry of Chitral especially in the surrounding of Chitral Gol national park, therefore this study aims to cover this gap and contribute to the literature.

\subsection{Objectives of the study}

This study has been conducted in the surrounding areas of Chitral Gol National park. The following are the objectives.

$\circ$ To estimate the cost, benefit and profit of the of the handicraft industry located in the surrounding of Gol National Park.

- To explore the factors determining the cost, benefit and profit of the handicraft products.

- To analyze the customers demand for the handicraft products.

- To analyze the potential of the handicraft businesses.

\section{Literature review}

Several prior studies highlighted the importance of handicraft businesses around the world. For instance, Terry (1999) explained the importance of handicraft in Botswana. Primary data has been collected through field survey. The findings of the study indicated a positive impact of handicraft industry on the Botswana economy. It is further concluded that production of handicraft is more beneficial than non-craft industry. Similarly, Rogerson and Sithole (2001) examined the production, problems and required support of handicraft in rural area of Mpumalanga, South Africa. They interview 60 individual for data collection. The results concluded that production and consumption of handicrafts in said area was linked with tourism. Baloch (2007) conducted a case study of Chitral valley, which revealed that tourism remained an underestimated industry from the beginning. He suggested that the government should focus on boosting up tourism in Pakistan.

Rafiq, Shafiqullah and Malik (2007) investigated the demand of recreation visits to Chitral. More than $80 \%$ of visitors were in favor of the quality site. It was recommended that a good quality of transportation and roads could bring increase in of the tourists flow to Chitral valley and imposing an entry fee will increase resources. Giron, Hernández and Castañeda (2007) observed the factors and strategies behind the success of handicraft sector of Mexico. They considered the marketing strategy as most important tool for this sector. They concluded that there are around 23 factors of success which are linked with the marketing strategy of these skilled labors. It is concluded that price strategy and personal recommendation in order to increase profit are important for this sector. Sirika (2008) examined the socio-economic position of handicraft females amongst Macca Oromo of West Wallaga, Southwest Ethiopia and concluded that artisan ladies are contributing to socioeconomic life the local residents. Producing diverse products in order to maintain a sustainable development is suggested. Murray (2010) identified an upward movement in 
embroidery designs by reviewing three case studies. The study observed that there was still lack of knowledge in these artisans. Khan, Syed, Zaman and Ahmad (2011) examined Student's awareness toward social, economic and environmental influences of tourism in Chitral using primary data. that the results showed that respondents were in favor of developing tourism in Chitral for better career opportunity.

Khan (2011) conducted a case study for analyzing handicraft industry in Sindh, Pakistan. It was concluded that the quality of handicrafts are decreasing over time. Changing taste of the people and production of latest goods are the mains reasons. Furthermore, the value chain has been violated and the interest of people has been decreased. In order to preserve the heritage of Pakistan, this sector needs to be focused by the government. Ghouse (2012) examined the problems and planning of handicraft industry in India. It is concluded that handicrafts play a vital role in the exports of emerging countries. It is predicted that the transformation of small businesses to the handicraft production might decrease in near future. Exports of handicraft products can decrease problems related to this sector. Bibi and Ali (2014) examined the influence of Aga Khan Rural Support Programme on women empowerment in Chitral through a field survey utilizing primary data. The findings revealed that respondents were in favor of Aga Khan Rural Support Programme. Survey explored that this programme improved the living standard of the people. Sheikh, Hazirullah and Khan (2014) examined the dresses and decoration tastes of women in District Chitral. For the empirical analysis primary data has been collected. The results indicated that the residents of the area are distinctive in everything from other people living in other parts of the country. Naidu, Chand and Southgate (2014) examined the key reasons of innovation in Fiji and Tonga handicraft industry. Primary data was collected from 368 respondents in Tonga and Fiji respectively. The results found that value addition, innovative merchandise development, design individuality, cultural individuality, progressive skill, skill of possessor, capability of possessor keep in touch with new trend in market, and the raw material quality cause innovation. Mahgoub and Alsoud (2015) examined the effect of handicrafts on the advancement of cultural and economic growth. Cross sectional data has been collected from 45 students of University of Khartoum, Sudan. The results indicated that cultural promotion and economic development are dependent on the handicrafts . Nyawo and Mubangizi (2015) investigated the role of local administration in the expansion of the art and craft area as a local economic growth initiative. Both primary and secondary data were utilized, which confirmed that the sector contributed to tourism in the study area.

Bano (2016) examined that the Indian handicrafts play a vital role in the economic growth of the country utilizing secondary data. The study focused on handmade carpets of the India. It has been explored that all of Indian handmade carpet production in a rural area can be exported. Makhdoom, Shah and Bhatti (2016) conducted a study on the handicraft industry role in the economic welfare in Badin, Pakistan. Primary data has been collected through questionnaire from 40 skilled women. They concluded that actual production of crafts is less than potential production and they earn very low amount and the main reason was lack of education and lack of awareness. It is suggested that personal shops for the products instead of providing it to the middleman for selling will increase the profit of the people. Fillis and Abisuga-Oyekunle (2016) investigated the effects of handicraft on employment of young people in South Africa. It is concluded that the production of handicrafts is comparatively lower against its potential in South Africa. Mitra and Paul (2017) conducted a case study on handicraft industry in district Birbhum, West Bengal. They concluded that handicraft industry was playing an important role in the Birbhum economy. Hassan, Tan, Rahman and Sade (2017) conducted research carried out a study on the handicraft industry in Malaysia. They concluded that handicraft industry can be developed through creation of entrepreneurial skills 
and awareness in young people. Chachar, Abbasi and Chachar (2018) examined the effects of owner's skills and education on handicraft industry in Pakistan. It was concluded that education and experience of owners promoted the handicraft businesses in the area. Similarly, a number of other studies including Shahbaz et al., (2019), Luqman et al., (2019), and Haseeb and Muhammad (2020) suggested that tourism play a vital role in the socio-economic development of a country. However, for this purpose, the local businesses needs to supported and promoted.

\section{Material and Methods}

This section discusses the data collection, theoretical framework and application of estimation techniques. The details are given below.

\subsection{Population and Sample Size Selection}

This study carried out an economic analysis of the handicraft industry in District Chitral. In District Chitral there are 6 Tehsils in which 49,794 people are living in urban areas, while rural population is 397,568. Mostly the crafts producers are living in rural areas. Producers are randomly interviewed according to their availability. It was impossible to reach to all producers due to the worst transportation facility and huge distance amongst all producers. The sample size for this study is 60 including 40 handicraft producers, 10 retailers and 10 customers in surrounding of Chitral Gol National Park. For the empirical analysis, primary data has been collected through a questionnaire and interview schedules from the producers, retailers and customers of handicraft products in surrounding areas (i.e. Chitral Town, Kalash valley and Drosh) of Chitral Gol national park. All the relevant information regarding the name, village, age and education, production details such as products, per unit time, working hours per day, experience, details about labor, raw materials and its costs, tools and costs, sales and supply. And Income, spending are included in the questionnaire and interview schedules.

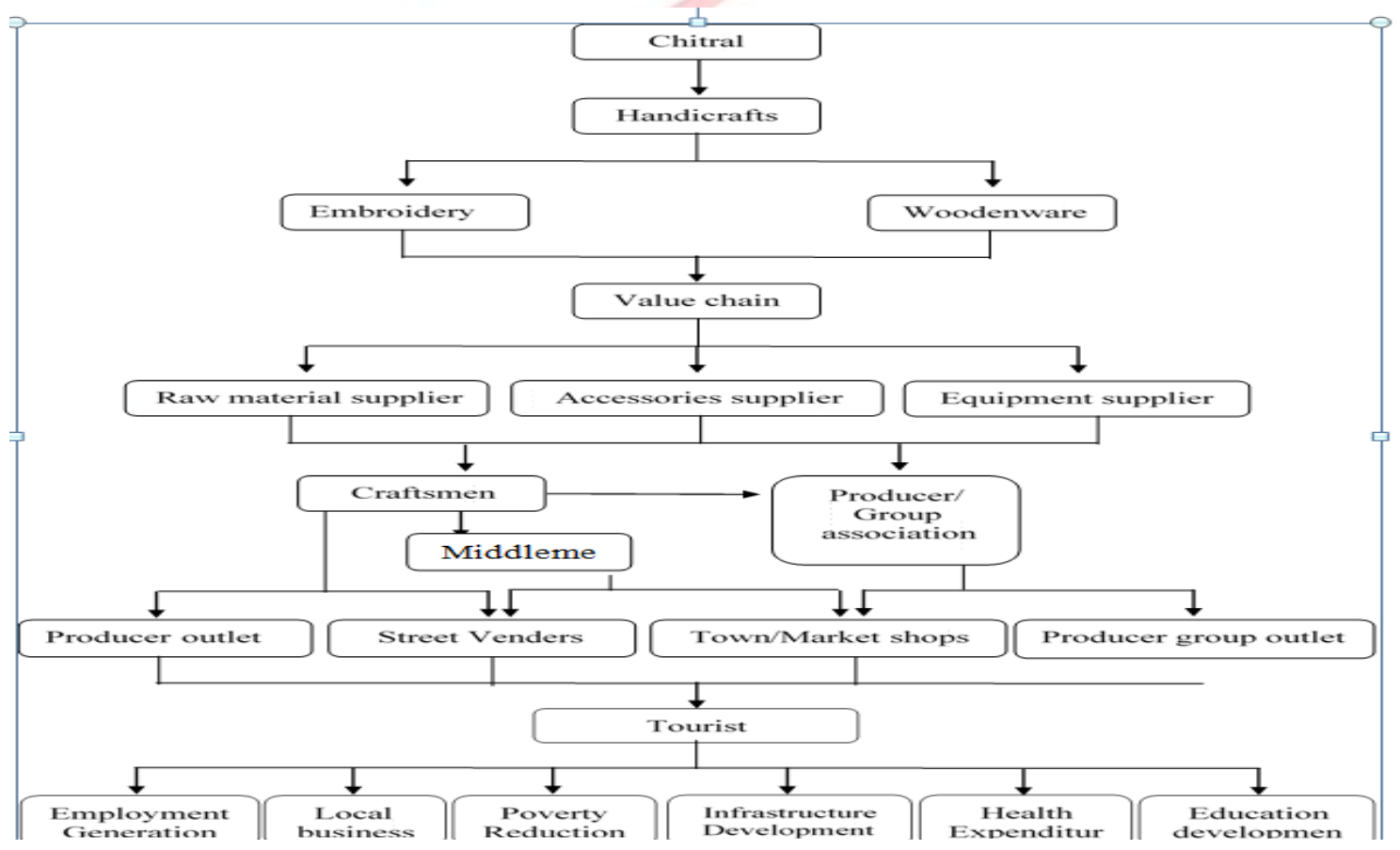

Figure-2: Value chain analysis Handicrafts Industry in Chitral 
Figure 2 illustrates the value chain of the handicraft industry in Chitral. There are two main dimensions of the handicrafts industry i.e. embroidery and woodenware, in which embroidery is more famous, value chain according to the figure starts from the raw material and equipment supplier which they provide to the large and small craft producers. After the production of the crafts, the craftsmen supply their products to producer outlets, street venders, middlemen and large producers. The middlemen then supply it to the street venders and local shops. Similarly, the large producers or groups supply the final products to the town shops and producer group outlet. The villagers and tourist purchases these products which in turn help in employment generation, encourages local business and reduce poverty, similarly it also helps in the development of infrastructure, promotes health facilities and develops education.

\subsection{Theoretical Framework}

Profits are the differences between revenues and costs. Profit can be maximized by increasing the output price or lowering the input cost. A firm having " $\mathrm{n}$ " products which are $y_{i} \ldots \ldots . y_{n}$ by utilizing $\mathrm{m}$ inputs that is $x_{\bar{i}} \ldots \ldots \ldots x_{m}$, so if the prices of products are $p_{i} \ldots \ldots p_{n}$, costs are $w_{i} \ldots \ldots \ldots w_{m}$ then the profit function can be written like as follows (Varian, 2014).

$$
\pi=\sum_{i=1}^{n} p_{i} y_{i}-\sum_{i=1}^{m} w_{i} x_{i}
$$

Equation 1 shows the profit function of a firm in this equation first term is the revenue while the $2^{\text {nd }}$ term is the cost. It is essential to include all input prices while measuring the profits for example all the factors of production should be included at their market value.

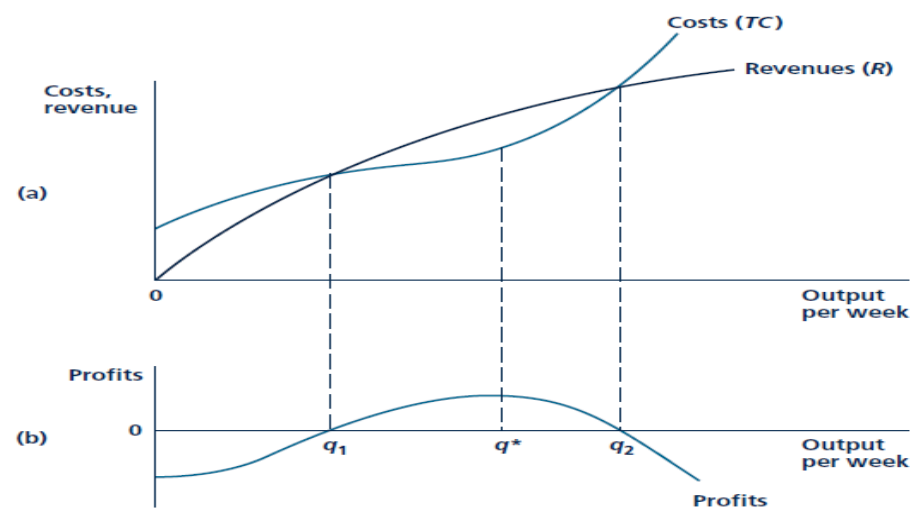

Source: (Nicholson \& Snyder 2009)

Figure-3: Profit, revenue and cost curves.

Figure 3 shows the revenue and cost curves in panel "a" while the profit curve in panel "b". According to the graph total cost curve started above zero due to the fix cost. There will be fix cost even with zero production. Therefore the total profit is negative. At point q1 when the firm increase revenue by increasing the production, the revenue curve intersects the cost curve resulting in the zero profit, at point $\mathrm{q}^{*}$ total cost is lower than the total revenue, therefore the profit is positive in pannel " $b$ ". 


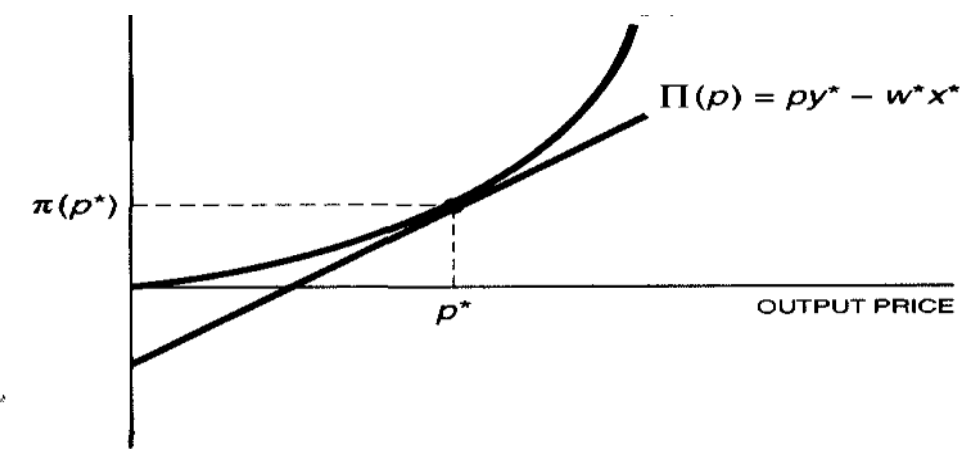

Source: (Varian 1992)

Figure-4: Profit function following active and passive strategies

Figure 4 shows the response of the producer at the output price rise. Straight line shows the profit function at passive policy. If producer follow passive policy so when the prices of output rise producer will continue on same production plan. On the other hand, if he changes his production plane according to the price rise, he will be at optimal policy. Profit in optimal policy should be at least higher than profit in the passive policy.

\subsection{Empirical Models and Estimation Techniques}

The empirical models are divided into three models. The first model is of profit equation, second model shows the cost equation and third model represent the revenue equation.

The profit equation is giving as follows.

PUP $P_{i}=a_{0}+a_{1}$ COM $_{i}+a_{2}$ ASM $_{i}+a_{3} T_{H}+a_{i} S O H_{i}+a_{5} S O E_{i}+\mu_{i}$

In equation 2 PUP is per unit profit and dependent variable. Whereas, the independent variables COM is the material cost on per unit product, ASM average sale per month, THI total household income, SOHs households spending on health, SOE is spending on education. Moreover, $a_{0}$ represents the constant and $a_{3} a_{2,} a_{3}, a_{4} a$ and $a_{5}$ are the coefficients and $\mu$ is the error term.

Similarly, equation (2) is the revenue function.

$$
\text { PUR }_{i}=\beta_{0}+\beta_{1} \text { COM }_{i}+\beta_{2} \text { THI }_{i}+\beta_{3} S O H_{i}+\beta_{4} S O E_{i}, \beta_{5} A S M_{i}+u_{i}
$$

In equation 3 PUR stands for per unit revenue which is the dependent variable. And COM, THI, SOH, SOE and ASM are explanatory variables. $\beta_{0}$ is constant and $\beta_{1}, \beta_{2}, \beta_{3}, \beta_{4}$ and $\beta_{5}$ are the coefficients and $u$ is the error term.

Finally, equation 4 shows the cost equation.

$$
P U C_{i}=\gamma_{0}+\gamma_{1} P U T_{i}+\gamma_{2} E_{i} P_{i}+\gamma_{3} C O M_{i}+\gamma_{4} C O T+\gamma_{5} A S M_{i}+v_{i}
$$

In equation 4 PUC is per unit cost and dependent variable. While, COM, THI, SOH, SOE and ASM are explanatory variables. $\gamma_{0}$ is the constant, while $\gamma_{1}, \gamma_{2} \gamma_{3}, \gamma_{4}$ and $\gamma_{5}$ are the coefficients and $v$ is the error term.

\section{Results and Discussion}

This section presents the study results and discussion. The details are presented as follows:

\subsection{General Survey Information}

The survey started from Drosh village. The climate of Drosh is comparatively warmer and dry. It is located on $35^{\circ} 33^{\prime} 33^{\prime \prime} \mathrm{N}$ and $71^{\circ} 47^{\prime} 44^{\prime \prime} \mathrm{E}$, with $51 \mathrm{~km}$ square area and with a distance of $30 \mathrm{~km}$ from the main City. The height of Drosh is 4459 from sea level. According to censes in 2011 it has 174, 860 population. Drosh village is located in starting of District Chitral. Handicrafts and dry fruits of Drosh are famous in all Chitral. Besides handicraft farming was the main source of their income. People of Chitral are very hard worker and 
healthy. Producers of embroidery are mostly female while males work in wood crafts. Producers have been interviewed by a local translator. Chitrali women proud of their skills and they wish to handover them to the next generation. They are skilled in different types of embroidery products, kushnil dresses are much liked by local customers and tourists, kushnil dress made from woolen thread keeps the body warm even in very cold weather, moreover, karahi is also very famous in Chitral, karahi designs are used in cloths, bedsheets, caps and other embroideries. Local female producers make these products with their hands. The raw material for these items are only cloth and thread, these items are made for wedding gifts, dowries and decoration pieces for their households.

The woodwork of Drosh is also very famous due to the fine quality of wood and skilled artesian. The tools which help in making wood crafts are called, Chausi, parkaal, Gunya, Geometry box, soven, randa, glender and regmal in their local language. The wood is obtained from the local forest. Wood items are mostly being purchased by local villagers. The living standard of average people was not very much satisfactory, reason was the low average of income, hard climate and worst transport facilities. According to the producers, this industry can further increase by government support in the shape of loans, training centers and access to other cities of Pakistan. The average level of their education was intermediate and they wished for further study but due to the responsibilities and low family income, they were unable to get higher education.

Chitral Town, which is the main city of District Chitral and comparatively more developed, dwellers of this town have comparatively higher literacy rate. Chitral airport is also located in Chitral town. Drosh to Chitral took almost 2 hours by road. Chitral is situated at 4921 feet height from the sea level and has 32 degree average temperature in July and August. Tirich Mir, which is one of the highest mountains of Pakistan can also be seen from Chitral town in clear weather. Chitral Gol national park was an hour's drive from the city. The national park has been visited on the same day. Any type of hunting is banned in this area according to the officials.

Producers of Chitral town were skilled in different types of embroidery, which are purchased by locals and tourists for home use and wedding gifts. Surmadaani is used to keep the kohl powder. It is commonly used in Chitral. Maata patties are used to wear on the newborn baby forehead to protect him from the evil eye. Most commonly produced embroidery products are the kushnil dresses made from the woolen thread, frequently used by adults and children of Chitral due to cold weather. The tools using in making kushnil are just the needles, but it take a long time to complete one full dress, it is purely made by hand, no machine is used in production. Time intensive products are comparatively expensive.

Girvan are widely used in the culture of Chitral. It is also used in the making of a bridal suite by pasting it on the shirt. Only cloth and thread are used as raw material and needles and frame are used as tools, these products are also time-intensive. Girvan are especially used in the dowry of the Chitrali females, during making their clothes, Girvan are placed on their shirts to make them more beautiful and attractive.

Karahi of Chitral is famous around the country, they are skilled in making Karahi on caps, clothes and bedsheets. A producer of wooden Markhor head has been found, he was making the model of Markhor very beautifully, according to the producer most of tourists demand for this piece. A producer making beautiful woolen shawl, cotton cloth and acrylic cloth with the help of a handloom machine was found during the survey. The raw materials for these products are obtained from Peshawar once a month. The tools used are handloom, shetal and baben.

Kalash valley is a land with unique culture with a very low population. It is situated at 5480 feet height from sea level. The climate of Kalash is comparatively cold. Distance from Chitral 
town is $15 \mathrm{~km}$ but it takes around 2 hours due to the worst road. The road to Kalash is very uncomfortable and tiring but has beautiful scenic views. Farming is the profession of mostly people of Kalash. Houses are made from wood in Kalash. The Kalasha people speak Kalasha language. Some have converted to Islam although most are believers of Ancient Hinduism. Beshalishi is the place of their worship, believers of other religions are not allowed to enter. In Kalash, there are many trees of walnut and apple. According to producers, Kalasha dress takes a month to complete and its demand is very low due to high cost. So they mostly produce it for self-use and for their festivals, they celebrate many festivals in a year i.e. Chilamjoshi festival, Uchal and Choimus. The most famous festival among these is the Chilamjoshi, which is also known as spring festival. Chilamjoshi starts from mid May and remains up to four days, they perform their traditional dance, men and women meet with each other to find a spouse for themselves. Uchal or Utchal starts in summer similarly Choimus is celebrated in winter.

When it comes to the way the Kalash dwellers costume, it is mostly the female clothes that catch the attention of the people. Kalasha females normally dress in long black robes, often embroidered with Cowrie shells. Therefore, they are also known in Chitral as "The Black Kafirs". These black robes are embroidered at collars, cuffs and hem and decorated with cowrie shells in a row with a very organized manner. They wear a special embroidered cap, called Kupas and shushuth in the Kalasha language and both are collectively called Cheelamjuski, which are very expensive and time-intensive in producing. All the raw materials are obtained from Peshawar and Karachi. It has been observed that there is no established channel of distribution and proper marketing for this creative and valuable work. Therefore bringing these handicrafts to other areas in Pakistan is extremely difficult. This sector remains a decentralized and unorganized sector of Pakistan's economy however it can be the most significant source of foreign exchange earnings. It is observed that this industry only produces for inner people's desire and fulfillment. Handicrafts of Chitral are categorized as handmade embroidery and woodenware crafts.

The handicraft industry has largely been neglected due to unawareness of households and the government. Being a main source of bread the promotion of handicrafts will have a positive impact on the lives of local inhabitants. It will attract more tourists for buying handmade embroideries and will generate income for the local producers and households. The revival of the handicraft industry in Chitral will certainly bring back handicraft experts migrated to the other part of the country for jobs. International marketing of the Chitral handicrafts will give a good name to this product and will increase the number of tourists in the area.

After reading the literature it has been noted that there is no work done on the handicraft industry of Chitral especially in the surrounding of Chitral Gol national park, therefore this study aims to cover this gap and contribute to the literature.

In general the literacy ratio is comparatively lower in Chitral against other districts. The main reason is their low standard of living. Table 1 shows the information regarding the Handicrafts producers education.

Table-1: Handicrafts Producer's Education Level in District Chitral

\begin{tabular}{cccccccc}
\hline Village & Primary & Middle & Matric & intermediate & Bachelor & Other & Total \\
\hline Chitral town & 0 & 2 & 4 & 1 & 1 & 0 & 8 \\
Drosh & 3 & 3 & 3 & 4 & 1 & 0 & 14 \\
Goldur & 1 & 4 & 0 & 1 & 0 & 0 & 6 \\
Jughoor & 0 & 3 & 2 & 2 & 1 & 0 & 8 \\
\hline
\end{tabular}




\begin{tabular}{cccccccc}
\hline Kalash & 1 & 2 & 0 & 0 & 0 & 1 & 4 \\
Total & 5 & 14 & 9 & 8 & 3 & 1 & 40 \\
\hline
\end{tabular}

Source: Field survey, 2019

The table depicted that out of 40 producers belonged to different areas, five were having primary education, fourteen middle, nine Matric, eight intermediate and three Bachelor. Similarly, table 2 shows the age information of the Handicraft producers.

Table-2: Handicraft Producers Age Wise Distribution

\begin{tabular}{cccc}
\hline Producer's age & Embroidery & Woodenware & Total \\
\hline Less than 21 & 2 & 0 & 2 \\
$21-30$ & 9 & 3 & 12 \\
$31-40$ & 9 & 4 & 13 \\
$41-50$ & 2 & 3 & 5 \\
51 and above & 5 & 3 & 8 \\
Total & 27 & 13 & 40 \\
\hline
\end{tabular}

Source: Field survey, 2019

It has been noted that out of the 40 respondents, 27 producers age was less than or equal to 40 years, 5 producers age was in the range of 41 to 50 years and 08 producers age was 51 years and above.

It is also important to mention that out of the 27 selected embroidery producers 25 were female and only 2 were male. Whereas, all the 13 selected producers running the woodenware businesses were male.

Table-3: Gender Ratio of Producers Engaged in Handicraft's Industry

\begin{tabular}{cccc}
\hline Gender & Embroidery & Woodenware & Total \\
Male & 2 & 13 & 15 \\
Female & 25 & 0 & 25 \\
Total & 27 & 13 & 40 \\
\hline
\end{tabular}

Source: Field survey, 2019

Table-4: Handicraft Customers Information

\begin{tabular}{cccc}
\hline Village/Area & Local & Tourists & Total \\
\hline Chitral town & 4 & 1 & 5 \\
Drosh & 3 & 0 & 3 \\
Kalash & 1 & 1 & 2 \\
Total & 8 & 2 & 10 \\
\hline
\end{tabular}

Source: field survey (2019)

Table 4 shows the total number of 10 customers were interviewed. Mostly customers were local while there were a less number of tourists. They believed that worse service of transportation is the main factor of less tourism and can be improved providing the better service of transportation. 10 customers have been interviewed in different areas, in which four customers were tourist while remaining six customers were local residents. Tourists in Kalash were very interested in buying the Kalashi dress but they were hesitating due to high price. They were praising the quality of Kalashi dress and other embroidery products. Tourist customers were suggesting to the government that government shall supply these products in 
other districts of Pakistan like Karachi, Lahore and Islamabad. Similarly they were also suggesting that better roads are necessary in order to explore all areas of Chitral which are worth to visit.

Table-5: Demand analysis of handicrafts from retailers

\begin{tabular}{ccccc} 
No of Customers & Min & Maxi & $\begin{array}{c}\text { Mean Sale per } \\
\text { day }\end{array}$ & SD \\
10 & 1 & 20 & 7.30 & 6.567 \\
\hline
\end{tabular}

Table 5 showed that retailers confirmed that they were selling a maximum of 20 items per day, and their product per day average demand was 7.30 items. Retailers purchase products from local producers. Sale of embroidery products is comparatively higher, according to the retailers. The customers mostly demanded for Kushnil dress and Karahi products. They believed that the future of handicraft is bright due to increase in tourism, because the demand is increasing every year and tourists are showing interest in Chitrali products. Furthermore, they explored that developing of Gol national park will positively affect this industry; the national park will attract the tourists from all around the world which will positively affect the demand and supply of this industry. The retailers were in favor of tourists' arrival and they suggest for the government to provide facilities for transport and infrastructure they also suggest to government to invest in handicraft industry to fulfill the expecting mass demand in future.

\subsection{Cost-Revenue Analysis}

This section provided information regarding the computation of the cost, revenue and profit of the embroidery and wooden ware producers.

Table-6: Revenue, Cost and Profit of Embroidery Producers

\begin{tabular}{|c|c|c|c|c|c|c|c|c|c|}
\hline S.N & Sale per week & $\begin{array}{l}\text { Reven } \\
\text { ue }\end{array}$ & Cost & $\begin{array}{l}\text { Profits } \\
\text { (R-C) }\end{array}$ & S.N & Sale per week & Revenue & Cost & $\begin{array}{l}\text { Profits } \\
\text { (R-C) }\end{array}$ \\
\hline 1 & 3 & 4800 & 3600 & 1200 & 15 & 3 & 6000 & 2400 & 3600 \\
\hline 2 & 5 & 7500 & 6000 & 1500 & 16 & 3 & 6000 & 3000 & 3000 \\
\hline \multirow{3}{*}{$\begin{array}{l}3 \\
4\end{array}$} & 2 & 36000 & 32000 & 4000 & 17 & 7 & 14000 & 10500 & 3500 \\
\hline & & 10000 & & & 18 & & & & \\
\hline & 5 & 0 & 6000 & 94000 & & 10 & 3500 & 2000 & 1500 \\
\hline 5 & 4 & 8000 & 6000 & 2000 & 19 & 10 & 5000 & 3000 & 2000 \\
\hline 6 & 3 & 6000 & 5100 & 900 & 20 & 20 & 12000 & 8000 & 4000 \\
\hline 7 & 8 & 28000 & 24000 & 4000 & 21 & 15 & 11250 & 7500 & 3750 \\
\hline 8 & 3 & 1140 & 900 & 240 & 22 & 5 & 15000 & 10000 & 5000 \\
\hline 9 & 2 & 4000 & 1200 & 2800 & 23 & 3 & 22500 & 10500 & 12000 \\
\hline 10 & 4 & 6000 & 2800 & 3200 & 24 & 1 & 35000 & 30000 & 5000 \\
\hline 11 & 4 & 4000 & 2000 & 2000 & 25 & 1 & 24000 & 20000 & 4000 \\
\hline 12 & 3 & 7500 & 1500 & 6000 & 26 & 1 & 28000 & 25000 & 3000 \\
\hline 13 & 3 & 5400 & 1500 & 3900 & 27 & 1 & 30000 & 25000 & 5000 \\
\hline \multirow[t]{2}{*}{14} & & & & & Total & 132 & & & \\
\hline & 3 & 2400 & 1800 & 600 & & & 432990 & 251300 & 181690 \\
\hline
\end{tabular}

Source: Field survey, 2019

Table 6 shows the revenues, costs and profits of multiple embroidery products in one week. Per unit revenue, cost and profit has been multiplied by total sale in a week. Survey explored that those product which are time intensive are more profitable. On the other hand, sale of less profitable products were comparatively higher. For example the production of Kalashi dress was time intensive product, therefore profit margin was comparatively higher but the sale of these products was very low, while normal karahi sale was comparatively higher but their profit margin was low. 
Table-7: Handicraft Producers Cost, Revenue and Profit from Wood Crafts.

\begin{tabular}{cccccccccc}
\hline S.N & $\begin{array}{c}\text { Sale } \\
\text { per } \\
\text { week }\end{array}$ & Revenues & Costs & $\begin{array}{c}\text { Profits } \\
(\mathbf{R}-\mathbf{C})\end{array}$ & $\begin{array}{c}\text { S.N } \\
\text { Sale } \\
\text { per } \\
\text { week }\end{array}$ & Revenues & Costs & $\begin{array}{c}\text { Profits } \\
\text { (R-C) }\end{array}$ \\
\hline 1 & 4 & 32000 & 20000 & 12000 & 8 & 2 & 80000 & 60000 & 20000 \\
2 & 2 & 16000 & 12000 & 4000 & 9 & 5 & 50000 & 40000 & 10000 \\
3 & 2 & 36000 & 30000 & 6000 & 10 & 3 & 54000 & 45000 & 9000 \\
4 & 1 & 60000 & 45000 & 15000 & 11 & 1 & 60000 & 50000 & 10000 \\
5 & 1 & 50000 & 35000 & 15000 & 12 & 3 & 105000 & 96000 & 9000 \\
6 & 2 & 40000 & 20000 & 20000 & 13 & 8 & 56000 & 40000 & 16000 \\
7 & 4 & 8000 & 3200 & 4800 & Total & 38 & 647000 & 496200 & 150800 \\
\hline
\end{tabular}

Source: Field survey, 2019

Table 7 describes the wood products profits in a week. Cost of production of wood material was higher than embroidery due to the cost of wood and tools therefore they charge higher prices of final wooden goods. Due to higher investment the profit margin was also higher as compared to embroidery.

Table-8: Total profit of Handicraft Producers

\begin{tabular}{llll}
\hline Business & Total Revenues(R) & Total Cost $(\mathbf{C})$ & $\begin{array}{l}\text { Total Profits }=\mathbf{R}- \\
\text { C }\end{array}$ \\
\hline Embroidery & 432990 & 251300 & 181690 \\
Woodenware & 647000 & 496200 & 150800 \\
Grand total & 1079990 & 747500 & 332490 \\
\hline
\end{tabular}

Source: Field survey, 2019

Table 8 shows the total revenue, total cost and total profit in a week. The table shows that the total revenue cost and profit from Embroidery and Woodenware businesses are Rs. 1079990, 747500 and 332490 respectively.

\subsection{Estimation Results}

In this section the descriptive statistics, correlation and regression results are presented.

Table-9: Descriptive statistics

\begin{tabular}{ccccc}
\hline Variables & Minimum & Maximum & Mean & Std. Deviation \\
PUP & 80 & 18800 & 3344.50 & 4567.820 \\
COM & 100 & 30000 & 5973.75 & 8633.722 \\
ASM & 14000 & 300000 & $5.16 \mathrm{E} 4$ & 57165.476 \\
SOE & 1000 & 30000 & 5400.00 & 5637.785 \\
SOH & 0 & 6000 & 2287.50 & 1612.799 \\
THI & 15000 & 70000 & $4.14 \mathrm{E} 4$ & 16055.493 \\
PUR & 350 & 60000 & $1.33 \mathrm{E} 4$ & 16911.692 \\
PUC & 200 & 50000 & 9912.50 & 13673.410 \\
PUT & 1 & 30 & 14.20 & 9.549 \\
EXP & 1 & 30 & 7.82 & 7.585 \\
COT & 50 & 80000 & 8915.00 & 13963.589 \\
\hline
\end{tabular}

Table 9 shows the descriptive statistics information. The table shows that the minimum cost on the production of one unit of handicraft product is Rs. 200 and maximum cost per unit of woodenware is Rs. 50,000. The average cost for both products was Rs. 9912. Similarly per 
unit profit of both products is within the range of Rs. 80 to Rs. 18800 with an average of Rs. 3344. The minimum cost of material is 100 while the maximum cost has been recorded 30,000 with average of 5973. The maximum experience of 30 years has been recorded while some producers were working from past 1 year in this business and the mean business years were 7.82. Per unit revenue was dependent on the craft some craft were very cheap on price like Rs 350, while the price of some products was up to 60,000 , therefore the mean price has been recorded 16911. 14000, 300000 and 51575 are the minimum, maximum and mean per month sale. Average total household income was recorded 41375, while the minimum and maximum values were 15000 and 70000 respectively. Profit per product was starting from 80 up to 15000 and the average profit per product was 4567 . The minimum spending on education was 1000 while the maximum spending was 30000 and 5400 was the average spending on education. People of Chitral were comparatively healthier therefore the monthly expenses of health were low, it was 2287 per month on average, while there were some people with zero health expenses. Producers explored that they spend 14 hours on making craft on average. Tools for the embroidery are cheaper than wooden crafts; therefore, the cost of tools is starting from 50 to 80000 with average of 8915 .

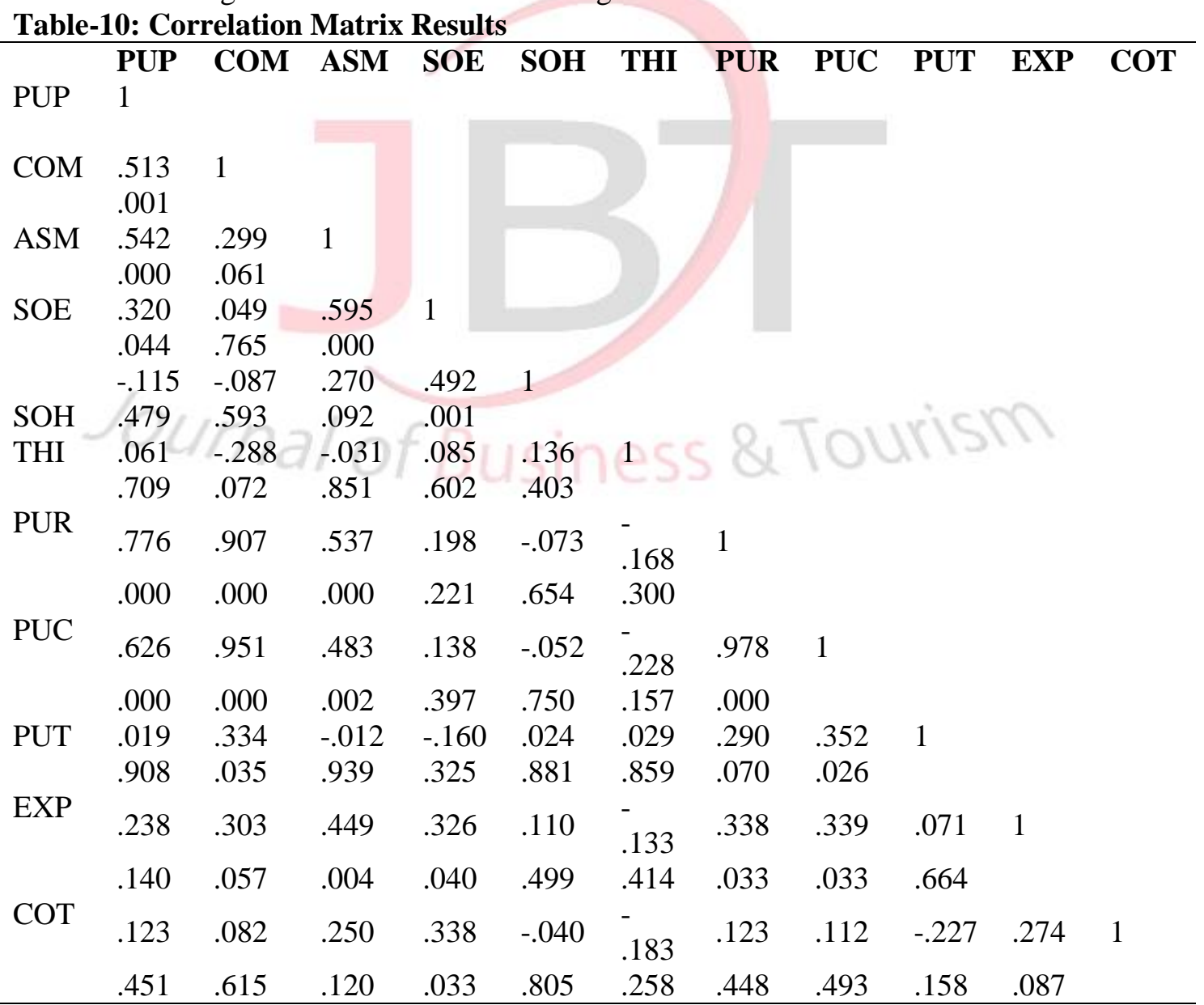

Table 10 shows the correlation matrix results. The table shows that profit is positively related with COM, ASM, SOE and THI have negative relationship with SOH. Similarly Per unit revenue is positively related with COM, ASM and SOE, and it showed a negative relationship 
with SOH and THI. Moreover, per unit cost is positively related with PUT, EXP, COT, ASM and COM.

\section{Table-11:Regression Results for Profit Model}

\begin{tabular}{cccccc}
\hline \multicolumn{7}{c}{$\begin{array}{c}\text { Unstandardized } \\
\text { Coefficients }\end{array}$} & $\begin{array}{c}\text { Standardized Coefficients } \\
\text { Variables }\end{array}$ & B & Std. Error & Beta & t & Sig. \\
\hline (Constant) & -1039.010 & 1778.302 & & -.584 & .563 \\
COM & .225 & .068 & .425 & 3.289 & .002 \\
ASM & .031 & .012 & .383 & 2.498 & .017 \\
SOH & -.888 & .382 & -.314 & -2.326 & .026 \\
THI & .063 & .035 & .220 & 1.798 & .081 \\
SOE & .168 & .130 & .207 & 1.289 & .206 \\
$\mathrm{R}^{2}: 0.54$ & Adj. $\mathrm{R}^{2}: 0.47$ & & & & \\
\hline
\end{tabular}

Table 11 shows the profit model results. It is found that cost of material is positively related with the profit, it has been also observed during survey that product with high material cost are more profitable, e.g. wood product. Similarly average sale is associated with profit, which means that increase in supply will increase per unit profit. Total household income is also positively related with the per unit profit. High level of income can help in investment which will reduce per unit cost and increase per unit profit. Spending on health has been shown inverse relationship with per unit profit. However, spending on education has been found insignificant.

Table-12: Regression Results for Revenue Model

\begin{tabular}{cccccc}
\hline Variables & $\begin{array}{c}\text { Unstandardized Coefficients } \\
\text { B }\end{array}$ & Std. Error & $\begin{array}{c}\text { Standardized } \\
\text { Coefficients } \\
\text { Beta }\end{array}$ & t & Sig. \\
\hline (Constant) & -3034.788 & 2818.803 & & -1.077 & .289 \\
COM & 1.629 & .108 & .832 & 15.046 & .000 \\
THI & .099 & .055 & .094 & 1.794 & .082 \\
SOH & -1.106 & .605 & -.105 & -1.827 & .077 \\
SOE & .050 & .207 & .017 & .243 & .809 \\
ASM & .092 & .019 & .310 & 4.716 & .000 \\
$\mathrm{R}^{2}: 0.95=1$ & Adj. $\mathrm{R}^{2}: 0.90$ & & & & \\
\hline $\mathrm{S}$
\end{tabular}

Similarly, table 12 shows the regression results for the revenue model. The results showed that the cost of material is positively related with revenue according to OLS results, which means that material cost will increase its revenue due to high price. Similarly average sale and household income variables are also positively related with revenue. Like profit function spending on health found negatively related with the per unit revenue. 
Table-13: Regression Results for Cost Model

\begin{tabular}{cccccc}
\hline \multicolumn{2}{c}{ Unstandardized Coefficients } & \multicolumn{2}{c}{ Standardized Coefficients } & \\
Variables & $\mathrm{B}$ & Std. Error & Beta & $\mathrm{t}$ & Sig. \\
\hline (Constant) & -2196.515 & 1135.431 & & -1.935 & .061 \\
& & & & & \\
PUT & 100.805 & 59.468 & .070 & 1.695 & .099 \\
EXP & -70.477 & 78.835 & -.039 & -.894 & .378 \\
COM & 1.372 & .068 & .866 & 20.237 & .000 \\
COT & .007 & .040 & .007 & .177 & .861 \\
ASM & .058 & .010 & .241 & 5.542 & .000 \\
$\mathrm{R}^{2}: 0.95$ & Adj. $\mathrm{R}^{2}: 0.94$ & & & & \\
\hline
\end{tabular}

Moreover, table 13 presented the cost model results. In the table the cost of the material is positively and significantly related with per unit cost. When material cost increases there will be an increase in product cost. Similarly like revenue function average sale is also positively related with the per unit cost variable. The variable of production time is also positively related with the per unit cost at 10 percent level of significance, which means that time intensive product will be comparatively more costly.

\section{Conclusion}

The study conducted an economic analysis of the handicraft industry in the surrounding of Gol National Park, Chitral. Specifically, the study estimated the cost, revenue and profit of the handicraft producers, demand for handicraft products and potential of the handicraft industry in the study area. Primary data from 60 respondents were collected including 40 handicraft producers, 10 retailers and 10 customers through a field survey in October 2019. From the producers, data has been collected through questionnaires and interview schedules are used for collecting data from retailers and customers. All the results are obtained through descriptive statistics, correlation and ordinary least square techniques. The weekly cost, revenue and profit of all the embroidery producers were Rs. 251300, Rs. 432990 and Rs. 181690. In contrast, the weekly cost, revenue and profit on wooden products of all producers were Rs. 496200, Rs. 647000 and Rs. 150800. It is also found that the average per month sale of a retailer selling both products and other items were Rs. 51600, and customers per day demand of handicraft products from a single retail shop was almost eight (08) items. Furthermore, the regression results showed that total household income and spending on education were positively related with the profit and revenue. And cost on material and average sale were positively related with per unit cost. It is concluded that handicraft industry contributing towards the income generation and standard of living of the handicraft producers in District Chitral.

\subsection{Policy Recommendations}

The policy recommendations based on the obtained results are given as under:

$\checkmark$ It has been observed that the living standard of the handicraft producers is poor. It is suggested that the government may start various schemes to provide financial support to the producers and promotion of this sector.

$\checkmark$ Poor transportation system is one of the main hurdle for the handicraft producers in supplying raw materials and final products, it should be improved.

$\checkmark$ All the government and non-government organizations need to provide financial assistance for promoting the handicraft industry. 
$\checkmark$ The government should also focus on the development of the national parks in the area This will increase tourists flow and demand for handicraft products. This will ultimately contribute to the development of handicraft industry and better standard of livings of the local producers.

\subsection{Limitations of the Study}

There are two national parks in District Chitral namely Broghil Valley National Park and Chitral Gol national park. Due to large distance between the two national parks and time and budget limitation the researcher was only able to conduct survey in surrounding areas of Chitral Gol national park.

\section{Acknowledgments}

I would like to express my deep and sincere gratitude to my research supervisors, Dr. Muhammad Tariq, and Dr. Muhammad Azam Khan, Department of Economics, Abdul Wali Khan University Mardan for giving me an opportunity in completion of this research project. I extend my heartfelt thanks to Mr. Muhammad Arif Orakzai, and the Khyber Pakhtunkhwa Wildlife Department for financial funding of this research project. I also thankful toMr. Irshad (District forest officer, Chitral) and Mr. Jahangir (Manager Chitral Gol Community Development and Conservation Association) for helping me in finding some producers of woodcrafts and embroidery.

\section{References}

Baloch, Q. B. (2007). Managing tourism in Pakistan: A case study of Chitral valley. Journal of Managerial Sciences, 2(2), 169-190.

Bano, R. (2016). Role of handicrafts in economic development: A case study of carpet industry of India. IRA-International Journal of Management \& Social Sciences, 4(3), 512-525.

Bibi, R., \& Ali, A. (2014). An assessment of economic interventions of AKRSP on the lives of women in Chitral. International Journal of Academic Research in Business and Social Sciences, 4(5), 562-571.

Chachar, A. A., Abbasi, Z., \&Chachar, A. A. (2018).Impact of owners' education and work experience on the growth of handicraft SMES in Pakistan. Grassroots, 51(2), 114131.

Fillis, I. R., \& Abisuga-Oyekunle, O. (2016). The role of handicraft micro-enterprises as a catalyst for youth employment. Creative Industries Journal.10 (1), 59-74.

Ghouse, S. M. (2012). Indian handicraft industry: problems and strategies. International Journal of Management Research and Reviews, 2(7), 1183.

Girón, J. D. L. P. H., Hernández, M. L. D., \& Castañeda, M. J. C. J. (2007). Strategy and factors for success: The Mexican handicraft sector. Performance Improvement, 46(8), $16-26$.

Hassan, H., Tan, S. K., Rahman, M. S., \& Sade, A. B. (2017).Preservation of Malaysian handicraft to support tourism development. International Journal of Entrepreneurship and Small Business, 32(3), 402-417.

Haseeb, M., \&Muhammad, A. (2020). Dynamic nexus among tourism, corruption, democracy and environmental degradation: a panel data investigation. Environment, Development and Sustainability, https://doi.org/10.1007/s10668-020-00832-9

Khan, A. J., Syed, S., Zaman, K., \& Ahmad, F. (2011). Students' perception toward social, economic and environmental impacts of tourism in Chiral, Pakistan. Journal of International Academic Research, 11(1), 1-8.

Khan, F. D. (2011).Preserving the heritage: a case study of handicrafts of Sindh, Pakistan.UniversitàCa' Foscari. 
Luqman, M., Arif, M., \& Khan, M.A., (2019). Socio-Economic Factors Determining Tourism in Sheik Baddin National Park DI Khan Khyber Pakhtunkhwa. Journal of Business and Tourism, 5(1), 75-90.

Mahgoub, Y. M., \& Alsoud, K. M. (2015).The Impact of handicrafts on the promotion of cultural and economic development for students of art education in higher education. Journal of Literature and Art Studies, 5(6), 471-479.

Makhdoom, T. R., Shah, S. A. A. S., Bhatti, K. (2016). Women's home-based handicraft industry and economic wellbeing: A case study of Badin Pakistan. The WomenAnnual Research Journal of Gender Studies, 8(8), 40-56.

Mitra, A., \& Paul, S. K. (2017). Entrepreneurial transformation: a study on rural handicrafts in the district of Birbhum, west Bengal. Jharkhand J. Development \& Mgmt. Studies, XISS, Ranchi, 15(1), 7211-7226.

Murray, K. (2010). Outsourcing the hand: An analysis of craft-design collaborations across the global divide. Craft+ Design Enquiry, 2(2), 1-24.

Naidu, S., Chand, A., \& Southgate, P. (2014). Determinants of innovation in the handicraft industry of Fiji and Tonga: An empirical analysis from a tourism perspective. Journal of Enterprising Communities: People and Places in the Global Economy, 8(4), 318330 .

Nicholson, W., \& Snyder, C. M. (2009. Intermediate microeconomics and its application. $11^{\text {th }}$ Edition, USA: South-Western College.

Nyawo, J., \& Mubangizi, B. C. (2015). Art and craft in local economic development: Tourism possibilities in Mtubatuba local municipality. African Journal of Hospitality, Tourism and Leisure, 4(2), 1-15.

Rafiq, M., Shafiqullah, M., \& Malik, A. (2007). Demand analysis of recreation visits to Chitral Valley: A natural resource management perspective. The Pakistan Development Review,46(4), 971-984.

Rogerson, C. M., \& Sithole, P. M. (2001). Rural handicraft production in Mpumalanga, South Africa: organization, problems and support needs. South African Geographical Journal, 83(2), 149-158.

Shahbaz, M.; Solarin, S. A., Azam, M. \& Tiwari, A. K. (2019). Tourism-induced income distribution in Malaysia: a practical experience of a truly Asian Economy. Current Issues in Tourism https://doi.org/10.1080/13683500.2019.1697648.

Sheikh, I., Naz, A., Hazirullah, W. K., \& Khan, N. (2014). An anthropological study of dress and adornment pattern among females of Kalash, district Chitral. Middle-East Journal of Scientific Research, 21(2), 385-95.

Sirika, B. (2008). Socio-economic status of handicraft women among Macca Oromo of West Wallaga, Southwest Ethiopia. Ethiopian Journal of Education and Sciences, 4(1) 114.

Terry, M. E. (1999). The economic and social significance of the handicraft industry in Botswana. Doctoral dissertation, SOAS University of London.

Varian, H. R. (2014). Intermediate microeconomics: a modern approach: $8^{\text {th }}$ International Student Edition. WW Norton \& Company.

Varian, H. R. (1992). Microeconomic analysis (Vol. 3). New York: Norton.

https://web.archive.org/web/20180424071915/http://www.pbscensus.gov.pk/sites/default/files /bwpsr/kp/chitral_summary.pdf. 